\title{
The Cycles of the Chinese Economy and Macroeconomic Regulation
}

\author{
Shucheng Liu*
}

\begin{abstract}
In the second half of 2003 and the first half of 2004, the Chinese Government adopted a moderately tight macroeconomic policy, which aroused widespread attention from home and abroad. This is because China's deepening of reform and openness has led to its increasing economic links with the outside world. Starting from analysing the characteristics of the Chinese economy in 2003, this article discusses the issue of contractive macroeconomic regulation. The article highlights that the growth of the Chinese economy in 2003 has two features. One is that China's per capita gross domestic product (GDP) exceeded US\$1,000, which indicates the Chinese economy may possibly maintain the momentum for rapid growth for a fairly long period. The second is that its year-to-year GDP growth reached 9.3 per cent, putting an end to the continual sliding trend of the economy between 1993 and 1999. It also put a stop to the Chinese economy's continual sluggish growth of between 7 and 8 per cent between 1998 and 2002, in the wake of the Asian financial crisis. The Chinese economy has embarked on a fast track in the new round of the economic cycle. However, in the third and fourth quarter of 2003 and the first quarter of 2004, China's GDP growth was as high as 9.6, 9.9 and 9.8 per cent, respectively, sparking a supply crisis in the coal, power, fuel and transportation sectors. As a result, important raw materials, such as steel and cement, faced a supply bottleneck and price inflation pressures intensified, Consequently, the Chinese Government, in a timely move, has adopted a moderately contractive macroeconomic policy to prevent the economy from fluctuating drastically and to avoid serious inflation to ensure a rapid, stable and sustainable economic growth. This is not only conducive to the growth of the country's economy itself, but also favorable for the development of the international trade and foreign investment in China.
\end{abstract}

Keywords: Economic Cycle, Macroeconomic Regulation, Economic Growth, China.

\section{CHINA'S CONTRACTIVE MACROECONOMIC POLICIES}

Between the second half of 2003 and the first half of 2004, the Chinese Government adopted a moderately tight macroeconomic regulatory policy, which aroused widespread attention from domestic and international economics and business circles. Since 1978, when it began to reform and open up to the outside world, China has adopted tight macroeconomic policies five times. The international community did not pay much attention to the four previous macroeconomic regulations. This time, the fifth macroeconomic regulation has aroused broad attention from the international community. This is because China's foreign economic links have increasingly widened as its reform and openness deepen. Between 1978 and 2003, China's import volume expanded from US\$10.9 billion to US\$412.8 billion, a 37-fold increase. In 2003, China became the third largest importer in the world. Seen from the perspective of aggregate volume, China's imports only account for 3.4 per cent of the world's total; seen from an increment perspective, however, China's import increments account for more than one third of the world's total import increments. In 2003, the foreign direct investment actually used in China was US\$53.5 billion, and China's foreign exchange reserves amounted to US\$403.3 billion. Overseas institutions, investors and media have engaged in extensive discussion on whether China's economic growth has been "overstretched" or "excessive" (in China, overstretched or excessive economic growth

Research Fellow, Director of the Institute of Economics, Chinese Academy of Social Sciences. 2 Yuetan Beixiaojie, Beijing 100836, P.R. China. E-mail: lushuch@mx.cei.gov.cn. 
is called economic overheating), and how best to perform a macroeconomic regulation, especially regarding the effect of the most recent macroeconomic regulations.

In terms of the effect of the most recent macroeconomic regulations, there are two schools of overseas arguments: optimistic and pessimistic. The optimistic camp holds that the tight macroeconomic regulation measures the Chinese Government has taken this time are much earlier than in previous rounds of economic overheating, which will, therefore, make the growth of the current Chinese economy more stable and sustainable. Pessimists mainly worry that if the central government's macroeconomic regulation policy caused an abrupt economic slowdown and led to a crash landing, it would have severe impact on the world economy, especially the economy of countries and regions around China. The Asia Wall Street Journal has highlighted that there are, nevertheless, more optimists than pessimists.

Since China adopted its reform and opening-up policy, the bilateral economic exchanges between China and South Korea, especially bilateral trade and South Korean investment in China, have developed rapidly. Therefore, China's most recent contractive macroeconomic regulation has also attracted extensive attention from South Korean economics and business circles. According to statistics from Chinese customs in 2002 and 2003, in terms of China's import volume, South Korea occupied the third place among countries and regions that export to China; China imported US $\$ 28.6$ billion and US $\$ 43.1$ billion, respectively (Table 1). In terms of China's export volume, South Korea took the fourth place among countries and regions to which China exports; China exported US\$15.5 billion and US\$20.1 billion in 2002 and 2003, respectively (Table 2). In terms of foreign direct investment in China, in 2002, South Korea took the fifth place among countries and regions directly investing in China; South Korean direct investment in China was registered at US $\$ 2.7$ billion. In 2003, South Korea rose to the third place, directly investing US $\$ 4.5$ billion in China (Table 3 ).

Table 1. China's Imports

\begin{tabular}{l|l|l|l|l|l}
\hline $\mathbf{2 0 0 2}$ & & \multicolumn{2}{l}{$\mathbf{2 0 0 3}$} & Countries and regions & $\begin{array}{l}\text { US\$1 } \\
\text { billion }\end{array}$ \\
\hline Place & Countries and regions & $\begin{array}{l}\text { US } \mathbf{1} \\
\text { billion }\end{array}$ & Place & & (44.1 \\
\hline \hline 1 & Japan & 53.5 & 1 & Japan & 49.4 \\
\hline 2 & Taiwan & 38.1 & 2 & Taiwan & $\mathbf{4 3 . 1}$ \\
\hline $\mathbf{3}$ & South Korea & $\mathbf{2 8 . 6}$ & $\mathbf{3}$ & South Korea & 33.9 \\
\hline 4 & US & 27.2 & 4 & US & 24.3 \\
\hline 5 & Germany & 16.4 & 5 & Germany & 14.0 \\
\hline 6 & Hong Kong, China & 10.7 & 6 & Malaysia & 11.1 \\
\hline 7 & Malaysia & 9.3 & 7 & Hong Kong, China & 10.5 \\
\hline 8 & Russia & 8.4 & 8 & Singapore & 9.7 \\
\hline 9 & Singapore & 7.0 & 9 & Russia & 7.3 \\
\hline 10 & Australia & 5.9 & 10 & Australia & \\
\hline
\end{tabular}


Table 2. China's Exports

\begin{tabular}{|c|c|c|c|c|c|}
\hline \multicolumn{3}{|l|}{2002} & \multicolumn{3}{|l|}{2003} \\
\hline Place & Countries and regions & $\begin{array}{l}\text { US\$1 } \\
\text { billion }\end{array}$ & Place & Countries and regions & $\begin{array}{l}\text { US\$1 } \\
\text { billion }\end{array}$ \\
\hline 1 & US & 69.9 & 1 & US & 92.5 \\
\hline 2 & Hong Kong, China & 58.5 & 2 & Hong Kong, China & 76.3 \\
\hline 3 & Japan & 48.4 & 3 & Japan & 59.4 \\
\hline 4 & South Korea & 15.5 & 4 & South Korea & 20.1 \\
\hline 5 & Germany & 11.4 & 5 & Germany & 17.4 \\
\hline 6 & Holland & 9.1 & 6 & Holland & 13.5 \\
\hline 7 & UK & 8.1 & 7 & UK & 10.8 \\
\hline 8 & Singapore & 7.0 & 8 & Taiwan & 9.0 \\
\hline 9 & Taiwan & 6.6 & 9 & Singapore & 8.9 \\
\hline 10 & Malaysia & 5.0 & 10 & France & 7.3 \\
\hline
\end{tabular}

Table 3. Foreign Direct Investment Actually Used in China

\begin{tabular}{l|l|l|l|l|l}
\hline $\mathbf{2 0 0 2}$ & Countries and regions & $\begin{array}{l}\text { US\$1 } \\
\text { billion }\end{array}$ & Place & Countries and regions & $\begin{array}{l}\text { US\$1 } \\
\text { billion }\end{array}$ \\
\hline \hline 1 & Hong Kong, China & 17.9 & 1 & Hong Kong, China & 17.7 \\
\hline 2 & US & 5.4 & 2 & Japan & 5.1 \\
\hline 3 & Japan & 4.2 & $\mathbf{3}$ & South Korea & $\mathbf{4 . 5}$ \\
\hline 4 & Taiwan & 4.0 & 4 & US & 4.2 \\
\hline $\mathbf{5}$ & South Korea & $\mathbf{2 . 7}$ & 5 & Taiwan & 3.4 \\
\hline 6 & Singapore & 2.3 & 6 & Singapore & 2.1 \\
\hline 7 & Germany & 0.93 & 7 & Germany & 0.86 \\
\hline 8 & UK & 0.89 & 8 & UK & 0.74 \\
\hline 9 & Canada & 0.59 & 9 & Holland & 0.73 \\
\hline 10 & France & 0.58 & 10 & France & 0.6 \\
\hline
\end{tabular}

Starting from the characteristics of Chinese economic growth in 2003, we will proceed to discuss the issue of China's current tight macroeconomic regulations.

\section{CHARACTERISTICS OF CHINA'S ECONOMIC GROWTH IN 2003}

The year 2003 was critical for China's economic growth as it demonstrated two benchmark characteristics: One is seen from the economic aggregate and per capita perspective; the other is from the angle of economic growth rate.

\section{A View from the Economic Aggregate and Per Capita Perspective}

China's GDP volume was 360 billion yuan (US\$43.4) in 1978. After seven years of reform and opening up in the $1980 \mathrm{~s}$, the figure reached one trillion yuan (US\$120.5 billion) in 1985 . Another five years later, it reached two trillion yuan (US\$240.96 billion) in 1990 . Since the middle of the 1990s, 
China's GDP has grown annually to ultimately reach 10 trillion yuan (US\$1.2 trillion). In 2003, the figure further rose to 11 trillion yuan (US\$1.33 trillion). The International Monetary Fund (IMF) uses the exchange rate-based method to calculate China's GDP, which is US\$1.4099 trillion (Figure 1).

Figure 1. China's GDP (1978-2003)

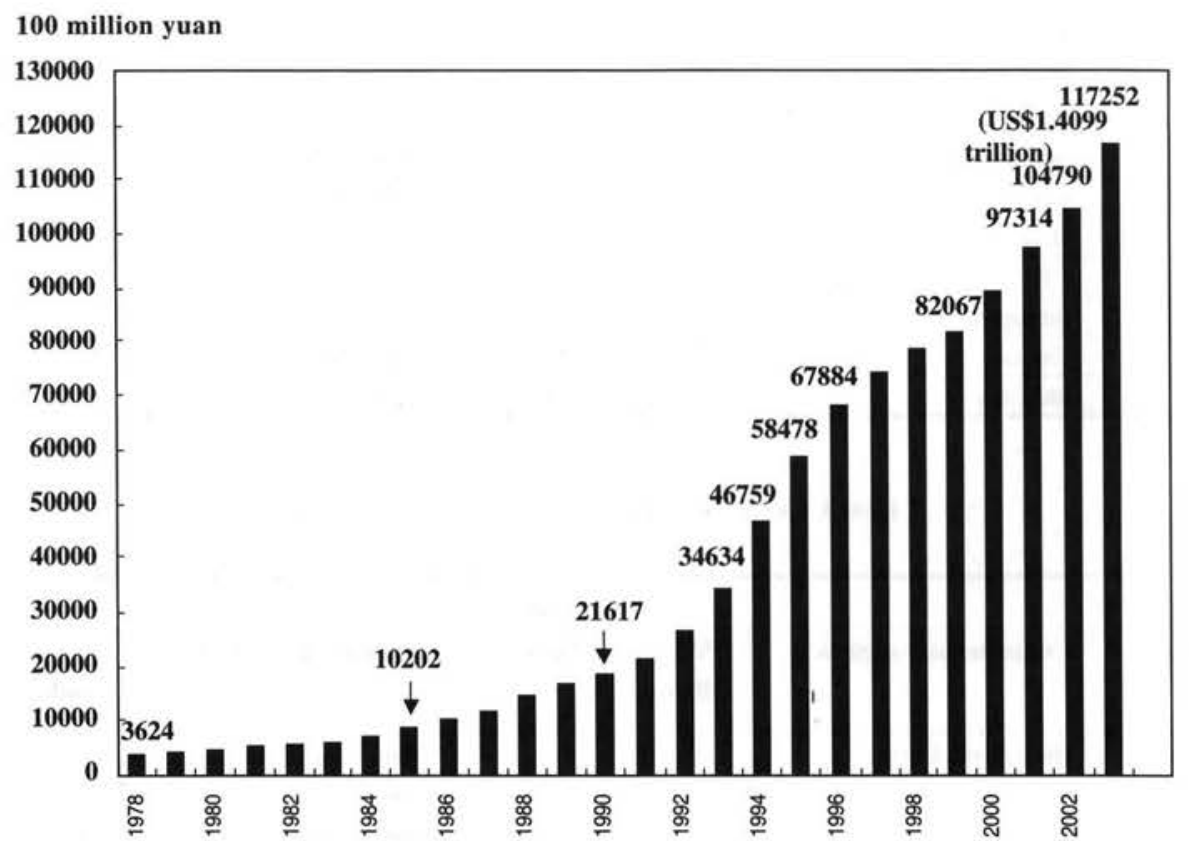

According to IMF statistics, China's GDP volume was the seventh largest of the world in 2003. The first ten leading economies were the United States, Japan, Germany, the United Kingdom, France, Italy, China, Canada, Spain and Mexico.

Seen from China's per capita GDP, the figure was below US $\$ 300$ the entire time from the early 1980s to 1987 (calculated in Figure 2 using the exchange rate of the specific year). In 2000, China's per capita GDP reached US\$856. In 2003, the per capita GDP broke through the benchmark line of US $\$ 1,000$ and reached US $\$ 1,100$ (calculated using the exchange rate of that year), marking a remarkable progress. Breaking through the line of US $\$ 1,000$ was an important event for China, which has a population of 1.3 billion. 
Figure 2. China's per capita GDP (1981-2003)

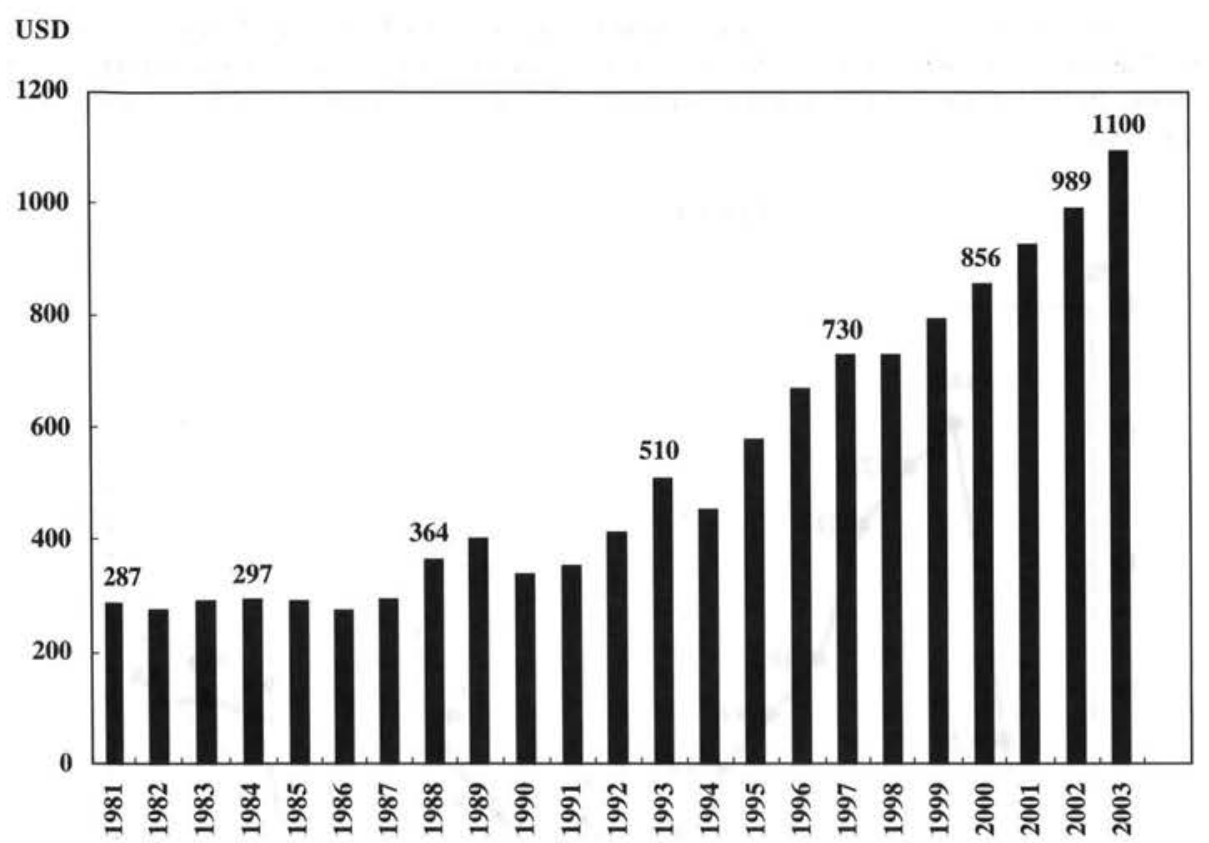

To sum up, the first characteristics of China's economic growth in 2003 was that its per capita GDP exceeded US $\$ 1,000$. This marked that China's economic growth has entered a very important stage, which can be examined from two perspectives. On the one hand, this may herald a golden period for China's development. Its industrialization and urbanization process may accelerate and the consumption structure may be improved, which will promote an ensuing upgrade in its industrial structure. The Chinese economy may continue to grow rapidly for a fairly long period of time. On the other hand, however, this may also be a period when economic and social contradictions take the stage. As the economic aggregate expands continually, consumption of resources will also increase, making the resource-constraint contradiction become even more prominent. As the social structure also undergoes profound changes, especially as the income gap widens, frictions among various interest groups may intensify. This demands that special attention be paid to a coordinated and balanced economic and social development to preclude the paradoxical scenario that the more dynamic the economy is, the worse the social contradictions.

\section{A View From the Economic Growth Rate Perspective}

The second characteristic of China's economic growth in 2003 is that its GDP growth reached 9.3 per cent. This puts an end to the continual downward trend of China's economic growth between 19093 and 1999, in the wake of the country's economic overheating in 1992. It also ends the scenario that China's economic growth had for many years lingered around 7 and 8 per cent, between 1998 and 2002, after the Asian financial crisis, rendering China on a fast track of development in the new round of the economic cycle. China's economic growth has been achieved during frequent fluctuations. We will now summarize the fluctuation history of the Chinese economy and the consequent lessons China has drawn since the 1990s. 


\section{CHINA'S ECONOMIC CYCLES SINCE THE 1990's}

In 1990 the low ebb of 3.8 per cent was reached in China's GDP growth (Figure 3). That was a counterbalance to the rapid economic growth that had occurred since China's reform and opening up in the 1980s. In 1991, China's GDP growth rebounded to 9.2 per cent, starting to embrace a new economic growth cycle.

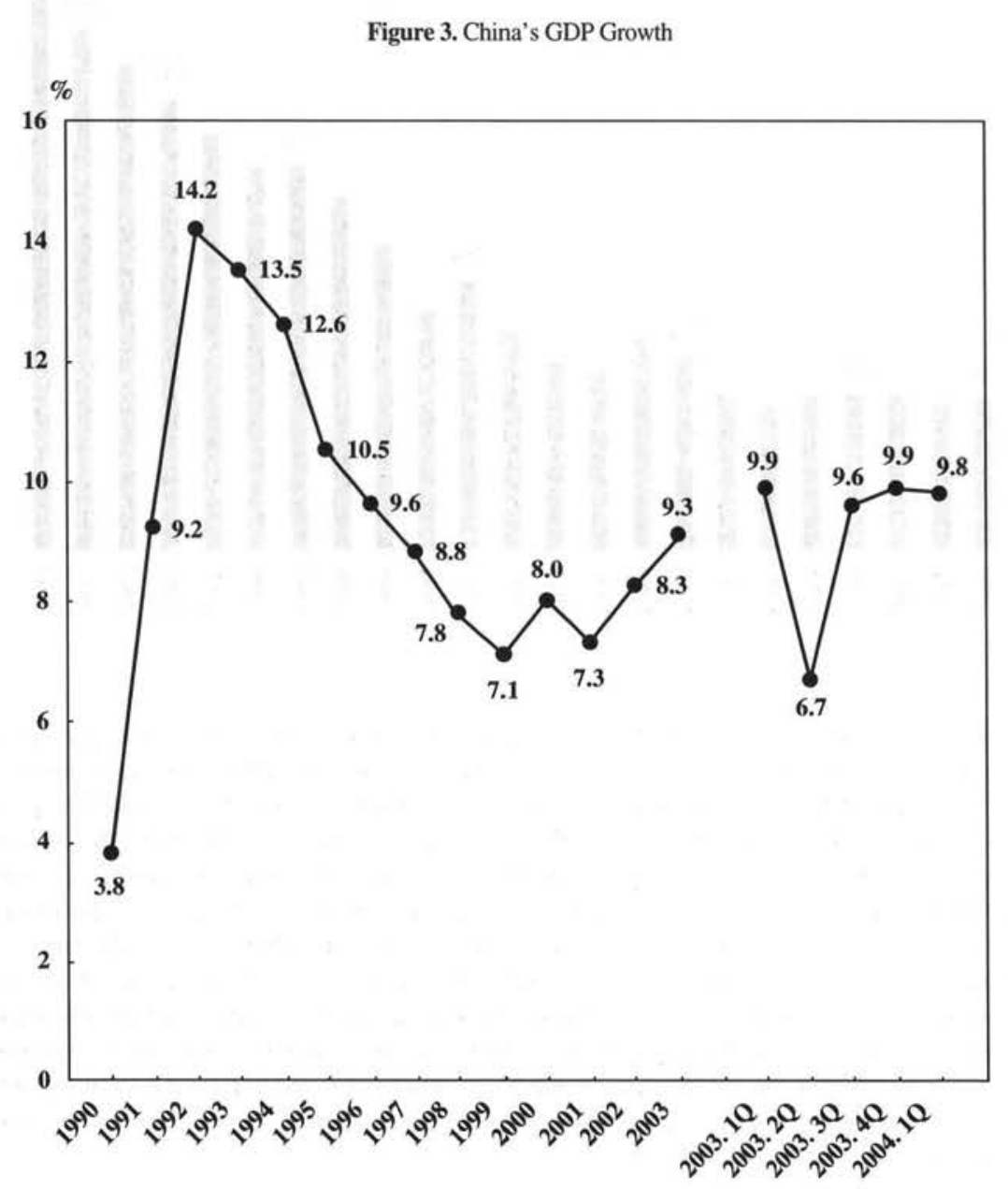

In 1992, China's GDP growth soon exceeded 10 per cent and reached the peak of 14.2 per cent. The over-expansion of the economy, or the overheating of economic growth, caused shortages of coal, power, fuel and transportation, and led to a supply bottleneck in raw materials, such as steel and cement. This situation resulted in financial disorder and price inflation. In the first half of 1993, the overheating trend in economic growth continued. In the middle of that year, the central government adopted a moderately contractionary macroeconomic regulation measures, including tightened monetary and fiscal policies, to hold down the volume of fixed asset investment and redress financial order.

Between 1993 and 1996 China's GDP growth gradually edged down. In 1993 it was 13.5 per cent, 12.6 per cent in 1994, 10.5 per cent in 1995; and in 1996 it slowed down further to 9.6 per cent. The 
average rate of decline was one percentage point per year. As the GDP growth slows down, the rise of prices (national commodity retail price rise) also dropped from its peak level of 21.7 per cent in 1994 to 6.1 per cent in 1996. Economic growth returned from a state of overheating to normal. We call this a success in achieving an economic soft-landing.

In July 1997, the Asian financial crisis erupted, which also spilled over to affect the Chinese economy. In the following years, starting from 1997, China's GDP growth declined further for three consecutive years. In 1997 it was 8.8 per cent; 7.8 per cent in 1998 and in 1999 declined to 7.1 per cent. To ward off the impact of the Asian financial crisis and solve the problem of inadequate effective domestic demand, the central government reoriented its macroeconomic regulation in 1998, heading for an expansionary fiscal policy (called "proactive fiscal policy" in China) and a neutral monetary policy (called "prudent monetary policy"). In 2000, China's GDP growth rebounded to 8 per cent. In 2001, affected by the U.S. economic adjustments (including the impact of the September 11 event) and the economic slow-down or recession that concurrently occurred in major developed countries, China's GDP fell to 7.3 per cent.

In 2002, China's GDP growth rose to 8.3 per cent. The next year, it further rose to 9.3 per cent. In the first quarter of 2003 , it was 9.9 per cent. By then, the continual downward economic growth spiral of 1993 to 1999 had ended, and China's economic growth stepped out of the scenario of lingering at 7 and 8 per cent between 1998 and 2002. China had embarked on an upward trend in the new economic cycle.

In the second quarter of 2003, affected by the SARS epidemic, China's GDP growth was 6.7 per cent, slightly down from the previous year. However, in the ensuing third and fourth quarters of the year, as well as the first quarter of last year, the GDP growth rate rose continually to 9.6 per cent, 9.9 per cent and 9.8 per cent, respectively. On the one hand, China's economic growth has risen from around 7 and 8 per cent in the wake of the Asian financial crisis to over 9 per cent, which is a hard-earned favorable trend. On the other hand, however, the growth rate of more than 9 per cent has neared the 10 per cent cap alert. The unduly rapid economic growth (including the over-expansion of fixed asset investment in some sectors and over-extension of credit by banks) has instantly caused a bottleneck in the supply of coal, power, fuel and transportation, and has led to the shortage of important raw materials such as steel and cement, intensifying price inflation pressures.

Seen from the practical experiences of its reform and opening up, especially from the perspective of its current resource supply of important raw materials, such as coal, power, oil and transportation, China's potential economic growth rate should be about 9 per cent, with a proper growth rate in the range of 8 to 10 per cent. If economic growth is below 8 per cent, it will be hard to provide adequate jobs, enterprises will encounter difficultly in growth, and social features will not develop smoothly. If it is higher than 10 per cent, a serious bottleneck in the supply of resources, such as energy, important raw materials and transportation, will occur, and economic operations will be pressed too hard. The ensuing economic structural imbalance and price inflation will make it very hard for rapid economic growth to be sustained. That is to say, the upper limit of economic growth can be roughly held at around 10 per cent. If it exceeded 10 per cent, it might possibly cause drastic economic fluctuation. In China, such fluctuation is called "violent ups and downs."

Since the founding of the People's Republic of China in 1953, the country has launched a largescale industrialization process. Until 1976, when the "Cultural Revolution" ended, China's economic growth fluctuation had undergone five economic cycles (Figure 4). From 1977 until the present, it has gone through another five economic cycles. In the first five cycles, there were three severe periods of fluctuation. In each period of fluctuation, the GDP growth was around 20 per cent (in 1958 it was 21.3 per cent; 18.3 per cent in 1964 and 19.4 per cent in 1970). Since 1977, there have been four periods of fluctuation, during which GDP growth was still obviously too high and exceeded 10 per cent, although it had slowed down in comparison to previous peaks (in 1978, it was 11.7 per cent, 15.2 per cent in 
1982,11.6 per cent in 1987 and 14.2 per cent in 1992). Historical experiences and lessons tell us that to maintain the sustainable and rapid growth of an economy, we must pay attention to the proper management of the peak spots of the GDP growth at the upward growth stage of the economic cycle. "Violent ups" must be precluded to iron out economic fluctuations.

Figure 4. Cyclical Fluctuation of China's Economic Growth (1953-2004)

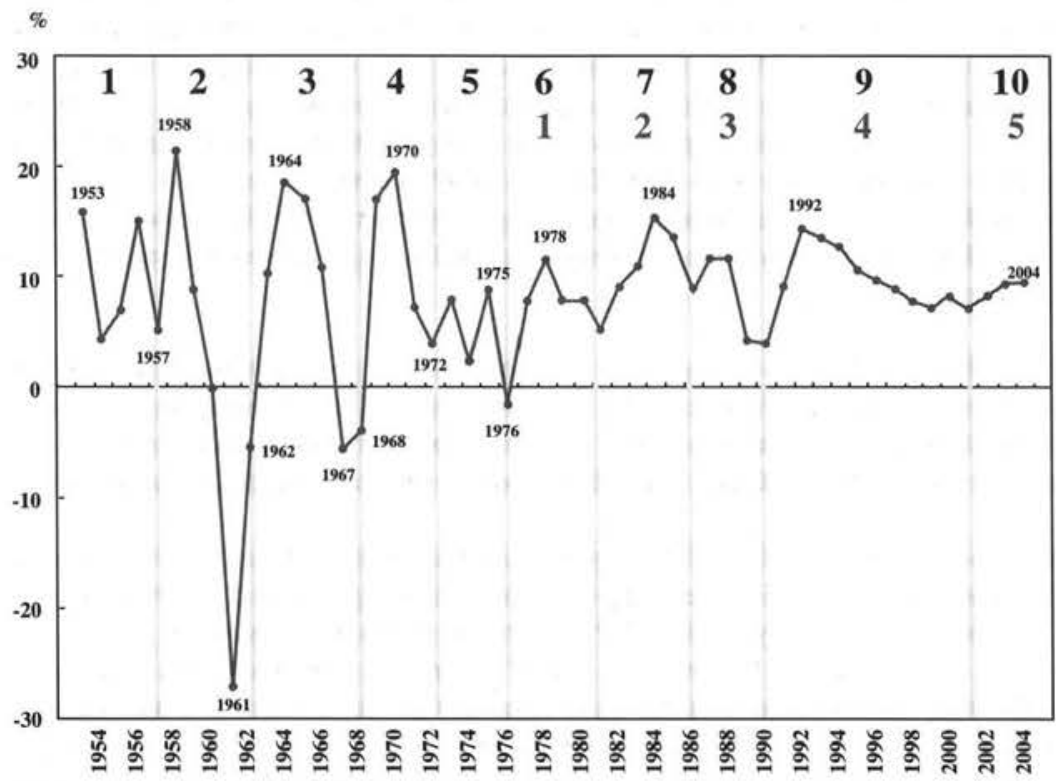

To maintain the country's rapid, stable and sustainable economic growth, the central government has, since the second half of 2003 and the first half of 2004, adopted a contractionary macroeconomic policy to prevent the economy from fluctuating violently and to ward off serious inflation.

China's rapid, stable and sustainable economic development and its success in precluding serious inflation are not only conducive to the economic development of the country itself, but also favorable for the development of international trade and foreign investment in China. It is predicted that in 2004 China's GDP growth may be 9 per cent or slightly higher, but below the 10 per cent cap alert level. The IMF predicted in the World Economic Outlook released in April 2004 that China's economic growth in 2004 would be 8.5 per cent; in the latest World Economic Outlook released in September 2004, it adjusted the figure up to 9 per cent. The rise in the consumer price index in 2004 is predicted to be about 4 per cent. The healthy development of the Chinese economy in 2004 has laid down a solid groundwork for its growth in 2005 and the following years, and is conducive to prolonging the span of the upward stage in the new economic cycle. It is predicted China's GDP growth in 2005 will still maintain economic growth between 8.5 to 9 per cent and that the consumer price index will grow by about 4 per cent. 


\section{REFERENCES}

CSSP, 2000, Prosperity and Stability - Study on China's Economic Fluctuations, Beijing, China Social Sciences Publishing House.

Liu Guoguang, Wang Luolin and Li Jingwen (chief compilers) and Liu Shucheng, Wang Tongsan( compilers), 2003a, Analysis of China's Economic Prospects ? Spring Reports of 2003, Spring Edition of the Economic Bluebook, Beijing, China Social Sciences Publishing House.

Liu Guoguang, Wang Luolin and Li Jingwen (chief compilers) and Liu Shucheng, Wang Tongsan( compilers), 2003b, Analysis and Forecasts of China's Economic Situation, Economic Bluebook, December, 2003, Beijing China Social Sciences Publishing House.

Liu Guoguang, Wang Luolin and Li Jingwen (chief compilers) and Liu Shucheng, Wang Tongsan( compilers), 2004, Analysis of China's Economic Prospects - Spring Reports of 2004, Spring Edition of the Economic Bluebook, Beijing, China Social Sciences Publishing House. 